\title{
Article \\ Topography Impacts Hydrology in the Sub-Humid Ethiopian Highlands
}

\author{
Demesew A. Mhiret ${ }^{1,2, *}$, Minychl G. Dersseh ${ }^{1,2} \mathbb{D}$, Christian D. Guzman ${ }^{3} \mathbb{D}$, Dessalegn C. Dagnew ${ }^{4} \mathbb{D}$, \\ Wubneh B. Abebe ${ }^{5} \mathbb{D}^{D}$, Fasikaw A. Zimale ${ }^{1} \mathbb{D}$, Benjamin F. Zaitchik ${ }^{6}$, Seifu A. Tilahun ${ }^{1} \mathbb{D}$, Kristine Walraevens ${ }^{7} \mathbb{D}$ \\ and Tammo S. Steenhuis $1,8, * \mathbb{D}$
}

check for updates

Citation: Mhiret, D.A.; Dersseh, M.G.; Guzman, C.D.; Dagnew, D.C.; Abebe, W.B.; Zimale, F.A.; Zaitchik, B.F.; Tilahun, S.A.; Walraevens, K.; Steenhuis, T.S. Topography Impacts Hydrology in the Sub-Humid Ethiopian Highlands. Water 2022, 14 , 196. https://doi.org/10.3390/ w14020196

Academic Editors: Aizhong Ye and Karl-Erich Lindenschmidt

Received: 29 October 2021 Accepted: 4 January 2022

Published: 11 January 2022

Publisher's Note: MDPI stays neutral with regard to jurisdictional claims in published maps and institutional affiliations.

Copyright: (C) 2022 by the authors. Licensee MDPI, Basel, Switzerland. This article is an open access article distributed under the terms and conditions of the Creative Commons Attribution (CC BY) license (https:// creativecommons.org/licenses/by/ $4.0 /)$.
1 Faculty of Civil and Water Resources Engineering, Bahir Dar Institute of Technology, Bahir Dar University, Bahir Dar P.O. Box 26, Ethiopia; minychl2009@gmail.com (M.G.D.); fasikaw@gmail.com (F.A.Z.); satadm86@gmail.com (S.A.T.)

2 Blue Nile Water Institute, Bahir Dar University, Bahir Dar P.O. Box 79, Ethiopia

3 Department of Civil and Environmental Engineering, University of Massachusetts, Amherst, MA 01003, USA; cdguzman@umass.edu

4 Institute of Disaster Risk Management and Food Security Studies, Bahir Dar University, Bahir Dar P.O. Box 5501, Ethiopia; cdessalegn@yahoo.com

5 Amhara Design and Supervision Works Enterprise (ADSWE), Bahir Dar P.O. Box 1921, Ethiopia; wubnehb@yahoo.com

6 Department of Earth and Planetary Sciences, Johns Hopkins University, Baltimore, MD 21218, USA; zaitchik@jhu.edu

7 Laboratory for Applied Geology and Hydrogeology, Ghent University, Krijgslaan 281-S8, 9000 Gent, Belgium; Kristine.Walraevens@ugent.be

8 Department of Biological and Environmental Engineering, Cornell University, Ithaca, NY 14850, USA

* Correspondence: demisalmaw@gmail.com (D.A.M.); tss1@cornell.edu (T.S.S.); Tel.: +251-91830-0305 (D.A.M.); +1-60-7255-2489 (T.S.S.)

\begin{abstract}
Understanding the relationship between topography, hydrological processes, and runoff source areas is essential in engineering design, such as predicting floods and implementing effective watershed management practices. This relationship is not well defined in the highlands with a monsoon climate and needs further study. The objective of this study is to relate topographic position and hydrological response in tropical highlands. The research was conducted in the Debre Mawi watershed in the northwest sub-humid Ethiopian highlands. In the monsoon rain phase of 2017 and 2018, groundwater depth, infiltration rate, and surface runoff were monitored at the upslope, midslope, and downslope positions. Surface runoff rates were measured in farmer fields through distributed V-notch weirs as estimates of positional runoff. Average water table depths were $30 \mathrm{~cm}$ deep in the downslope regions and $95 \mathrm{~cm}$ in the upslope position. The water table depth affected the steady-state infiltration rate in the rain phase. It was high upslope $\left(350 \mathrm{~mm} \mathrm{~h}^{-1}\right)$, low midslope (49 $\mathrm{mm} \mathrm{h}^{-1}$ ), and zero downslope. In 2017, the average runoff coefficients were 0.29 for the upslope and midslope and 0.73 downslope. Thus, topographic position affects all aspects of the watershed hydrology in the humid highlands and is critical in determining runoff response.
\end{abstract}

Keywords: Ethiopia; highlands; monsoon; distributed runoff; hydrological response; perched groundwater; infiltration; topography; watershed

\section{Introduction}

Globally, thousands of studies have been conducted to understand the amount of runoff generated in response to a hydrological event. Rainfall characteristics, topography, soil moisture, infiltration capacity, and land use have been identified as critical factors [1-4]. In the humid Ethiopian highlands, where the volcanic-derived soils have a high infiltration capacity, soil moisture governs runoff processes [1,2]. It means that any rain will infiltrate unless the soil is saturated, at which point all rain that is not lost as interflow will become 
runoff $[5,6]$. In addition, interflow is an important component of the discharge at the outlet $[2,7]$. According to previous research [6-10], topography is one of the main factors that impacts watershed hydrology, especially in humid climates. Studies in the Ethiopian highlands $[6,11]$ have shown that topographic factors affect catchment runoff more than ecological ones. In addition, studies based on the topographic wetness index map [12,13] confirmed that topography is a significant factor in catchment response. Based on topography, three topographic positions can be defined: upslope, midslope, and downslope. Upslope positions are the upper portions of the watershed close to the watershed divide and have deep permanent groundwater tables but can have perched groundwater above a hardpan. Midslopes are usually the steepest part in the watershed, where soils drain fast and remain unsaturated throughout the rain phase. Downslope regions close to the watershed outlet are in the lowest topographic position, saturating during the last half of the rain phase [2,14].

The (perched) groundwater table depth at any of the three landscape positions is a function of the quantity of incoming flow and the carrying capacity of the soil profile. The incoming flow depends on the rainfall falling on the contributing upslope area over the travel time from the divide $[15,16]$. The carrying capacity depends on the slope, hydraulic conductivity, and soil profile depth above the hardpan. For this reason, the least sloping and the downslope regions of the watershed usually have shallow groundwater tables, and steeper parts remain mainly unsaturated [17].

Despite many watershed experiments carried out in the Ethiopian highlands [18], few have investigated experimentally the effect of topographic position (upslope, midslope, and downslope) on runoff from soil and water conservation practices located at different parts of the watershed. Observations of runoff, either at the outlet of watersheds or from field plots, cannot distinguish the effect of topography on runoff generation [19] because discharge measurements at the outlet integrate all watershed runoff processes, and plot studies are hydrologically disconnected from the surrounding area [20]. Thus, the objective is to relate experimentally discharge to the topographic position in the landscape (upslope, midslope, and downslope). The investigations were carried out in the well-characterized Debre Mawi watershed in the Ethiopian highlands, $30 \mathrm{~km}$ south of Lake Tana [21-29].

\section{Materials and Methods}

\subsection{Description of the Study Area}

The study was conducted in the 95 ha Debre Mawi watershed in the sub-humid highlands of Ethiopia. The Debre Mawi watershed (Figure 1) is in the upper Blue Nile Basin, Ethiopia. The watershed is $30 \mathrm{~km}$ southeast of Bahir Dar on the road to Adet. The outlet is located at $37^{\circ} 22^{\prime} \mathrm{E}$ and $11^{\circ} 18^{\prime} \mathrm{N}$. The elevation ranges from $2195 \mathrm{~m}$ a.s.l. near the outlet to $2308 \mathrm{~m}$ a.s.l. in the southeast. Slopes vary from 1 to $30 \%$. The climate is sub-humid with a mean annual rainfall of $1240 \mathrm{~mm} \mathrm{a}^{-1}$. Eighty percent of the rainfall occurs from June to September. The mean daily temperature is $20^{\circ} \mathrm{C}$.

The hydrology, erosion, and gully formation in the Debre Mawi watershed have been studied over nine years, starting in 2010 [2,17,21-29]. During this period, $50 \mathrm{~cm}$ deep government-mandated infiltration furrows were installed [23], the eucalyptus tree acreage was expanded, and the road was asphalted at the northern edge [24,25]. Runoff and sediment concentrations were measured at the outlet of the 95 ha watershed and four nested watersheds [22]. Gullies within the watershed delivered most of the sediment at the outlet [28]. The runoff and erosion steadily declined over the nine years, mainly because the amount of rainfall needed for runoff to occur increased due to drying out of the watershed caused by the evaporation of the additional acreage of full-grown eucalyptus tree stands during the summer $[23,24]$. 


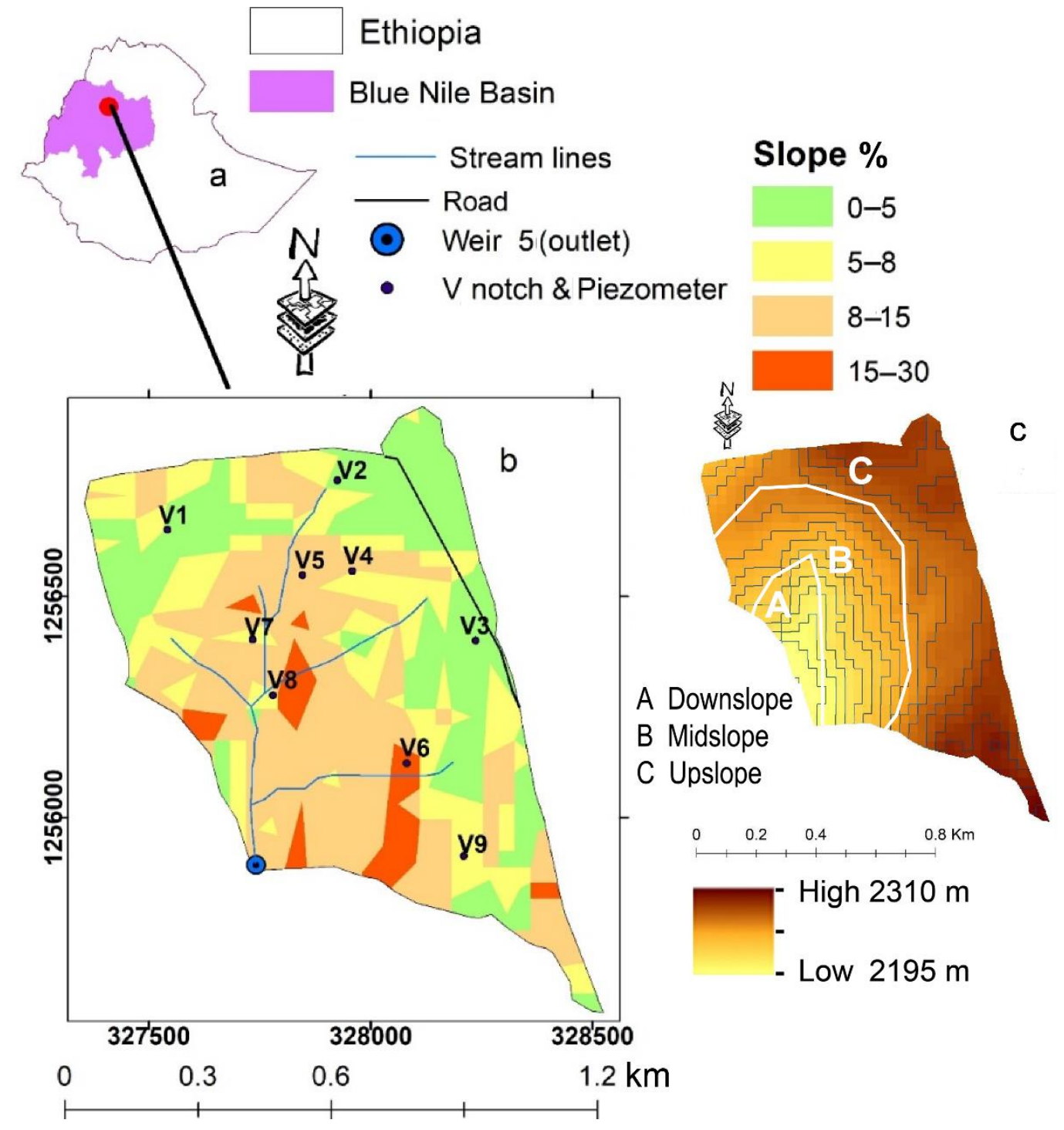

Figure 1. The Debre Mawi watershed in northwest Ethiopia. (a) Ethiopia; (b) Debre Mawi watershed with V-notch weirs (V1-V9) to measure runoff, perched groundwater depth, and infiltration rate measuring sites are near V-notch weirs; (c) digital elevation map.

\subsubsection{Topographic Units}

Upslope: This is the upper portion of the watershed close to the watershed divide characterized by slopes between 1 and $6 \%$. The soils are predominantly Nitisols. Nitisols are fertile forest soils with medium base saturation. The soils are deep, well-drained, permeable soils and suited for cereal cultivation such as teff (Eragrostis abyssinica), maize (Zea mays), finger millet (Eleusine coracana), barley (Hordeum vulgare), and wheat (Triticum aestivum). Soil and water conservation practices implemented during 2012, 2013, and 2014 consisted mainly of $50 \mathrm{~cm}$ deep infiltration furrows with bunds downhill. In 2017 and 2018, all the infiltration furrows were filled up with sediment. The bunds were still present and often concentrated the diffuse runoff upslope [25].

Midslope: These are located midway between upslope and downslope. The slope ranges from $6 \%$ to $30 \%$. The landscape consists mainly of reddish-brown vertic nitisols with good permeability on slopes $6-15 \%$ suited for growing teff [17]. The remaining area is steeper and consists of shallow rocky soils with bushes, shrubs, and grasses. Soil bunds and stone-faced soil bunds with infiltration furrows were constructed in the period from 2012 to 2014 [25]. 
Downslope: These are the periodically saturated or nearly saturated bottomlands during the rainy season and very close to the watershed outlet. The maximum slope is $6 \%$. The soils are vertisols. They consist of expanding montmorillonite heavy clay. Shrinkage cracks form during the dry monsoon phase and swell when wet. The soils are deep. Land use depends on the water table height. Lands that are continuously saturated during the rain phase are covered with grass. Other lands saturate for a short time are used for cereal production with teff as the main crop. Infiltration furrows with downhill bunds were constructed in 2013 and 2014. Most structures collapsed shortly after implementation, and one initiated a gully that was $3 \mathrm{~m}$ deep, $4 \mathrm{~m}$ wide, and $40 \mathrm{~m}$ long in 2017 [23-25].

\subsubsection{Geology}

Most of the watershed is underlain by highly weathered and fractured basalt similar to the regional geology of volcanic flows and pyroclastic fall Cenozoic deposits [26,27]. In the upper parts of the watershed, the fractured basalt is between 20 and $60 \mathrm{~cm}$. In the remainder, the basalt is much deeper at around 10-15 $\mathrm{m}$ [17]. The fractured bedrock is overlain by a $\mathrm{C}$ horizon of dark brown compacted clay $\mathrm{C}$ horizon followed by a light brown wet and sticky clay soil in the B horizon. Finally, the A horizon consists of either red or black clays or organic-rich soil [26].

A perched water table is formed on top of the deep basalt during the rain phase and then disappears three to four months after the rains stop [17]. Lava intrusions perpendicular to the slope force the lateral subsurface flow to the surface [22-25]. Faults act as the only flow conduct after the perched water table is absent [17].

\subsubsection{Eucalyptus Tree Expansion}

Farmers planted eucalyptus trees as a cash crop throughout the watershed, but mainly downslope. The wood was used for fuel and construction in nearby towns. Farmers recognized that eucalyptus decreased soil saturation and prevented gully formation [24].

\subsubsection{Experimental Fields}

The experimental fields were selected based on landscape position. Three fields were selected from each landscape position to represent the whole landscape unit. The two consecutive infiltration furrows bounded the fields with bunds. The length of the bunds in which we installed V-notch weirs was $51 \mathrm{~m}, 47 \mathrm{~m}$, and $51 \mathrm{~m}$ in the upslope; $46 \mathrm{~m}, 38 \mathrm{~m}$, and $49 \mathrm{~m}$ midslope; and $45 \mathrm{~m}, 57 \mathrm{~m}$, and $48 \mathrm{~m}$ in the downslope positions. The area of each experimental field is given in Table 1 . The total area upslope was $3700 \mathrm{~m}^{2}$, midslope $3800 \mathrm{~m}^{2}$, and downslopes $1500 \mathrm{~m}^{2}$. All the experimental fields were constructed starting at the beginning of July 2017. Measurements began in July 2017 and 2018 before any runoff was observed. The fields were not disconnected from the surrounding area, and we tracked the contributing areas using GPS. The runoff was directed to the V-notch weirs through the infiltration furrows after being reshaped to their original size (Figure 2).

All fields were cultivated to a $10-15 \mathrm{~cm}$ depth with the traditional Maresha plow by farmers. In the upslope, teff was grown on two out of the three experimental fields and finger millet on the third in both years (Table 1). The average slope of upslope fields was $5 \%$. In the midslope, two of the experimental fields were cropped with teff and one with wheat. Slopes ranged from 10 to $19 \%$, with an average slope of $14 \%$. The annual crops in the downslope experimental fields were teff, with an average slope of $6 \%$ in the downslope (Table 1 ). 
Table 1. Attributes of experimental fields in the Debre Mawi watershed. P1-P12 piezometers installed to measure water table depth at several V-notch weirs.

\begin{tabular}{|c|c|c|c|c|c|c|}
\hline $\begin{array}{c}\text { Field ID } \\
\text { (Piezometer) }\end{array}$ & $\begin{array}{c}\text { Topographic } \\
\text { Position }\end{array}$ & Area $\left(m^{2}\right)$ & Slope (\%) & Soil Type & Crop Grown & $\begin{array}{l}\text { Bund Length } \\
\text { (m) }\end{array}$ \\
\hline V1 (P1-2) & upslope 1 & 2200 & 6 & Nitisols & teff & 51 \\
\hline $\mathrm{V} 2$ & upslope 2 & 600 & 4 & Nitisols & teff & 47 \\
\hline V3 & upslope 3 & 900 & 5 & Nitisols & Finger millet & 51 \\
\hline V4 (P3-4) & midslope 4 & 2400 & 10 & Nitic-Vertisols & teff & 56 \\
\hline V5 (P5-6) & midslope 5 & 800 & 12 & Nitic-Vertisols & wheat & 18 \\
\hline V6 & midslope 6 & 600 & 19 & Nitic-Vertisols & teff & 49 \\
\hline V7 (P7-8) & downslope 7 & 400 & 5 & Vertisols & teff & 35 \\
\hline V8 (P9-10) & downslope 8 & 500 & 6 & Vertisols & teff & 37 \\
\hline V9 (P11-12) & downslope 9 & 600 & 6 & Vertisols & teff & 28 \\
\hline
\end{tabular}

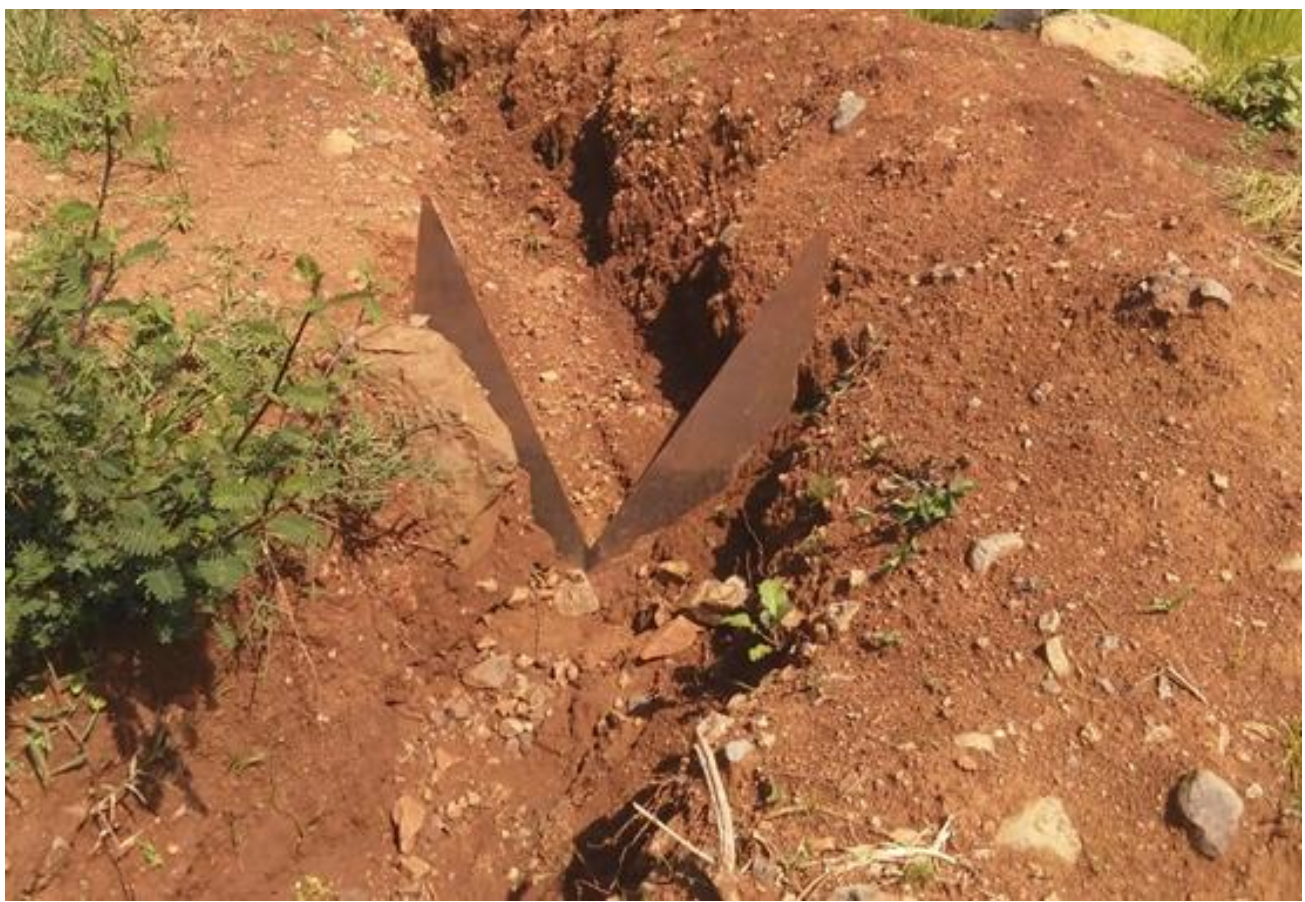

Figure 2. A typical triangular V-notch weir installed on the infiltration furrows at upslope positions of the Debre Mawi watershed.

\subsection{Data and Methods}

Precipitation: The daily rainfall was recorded with an automatic tipping-bucket rain gauge installed at the watershed center at $37^{\circ} 25^{\prime} 21^{\prime \prime} \mathrm{E}$ and $11^{\circ} 21^{\prime} 31^{\prime \prime} \mathrm{N}$. Precipitation was measured during the rainy season of 2017 and 2018 from June to October). Data from the nearby Adet Agricultural Research Center, $7 \mathrm{~km}$ south of the watershed, was used to fill the three days with missing data in 2017.

Surface runoff: The surface runoff was measured by installing 60-degree V-notch weirs made of metal sheets in the three topographic positions for the rainy season of 2017 and 2018 (Figure 1). Three V-notches were installed in each topographic position in the experimental fields at the outlet of the infiltration furrows at the lowest point of the field (Figure 2). The duration at a particular depth and the depth of flow over the furrows were measured manually. The runoff started relatively late the third week of July due to the eucalyptus trees in the watershed that dried out the soil during the dry phase and delayed saturation compared to earlier years [24,25]. In both study years, the data collection started on 21-June and stopped when the rainfall ceased in September. 
The discharge over the V-notch weirs was calculated using the V-notch equation [30].

$$
Q=\frac{8}{15} C d \sqrt{2 g} \tan \left(\frac{\theta}{2}\right) h^{2.5}
$$

where $Q$ is the discharge in $\mathrm{m}^{3} \mathrm{~s}^{-1}, \theta$ is V-notch angle between the sides, $g$ is the gravitational acceleration, $h$ is the head above the vertex of the V-notch weir in $\mathrm{cm}$, and $C d$ is discharge coefficient. The discharge coefficient $(C d)$ was [31].

$$
C d=\frac{0.585}{(\tan \theta / 2)^{0.004} h^{0.03}}
$$

The depth of surface runoff was calculated by dividing the runoff volume by the size of the field. Runoff from all the fields was measured only during the daytime due to difficulties reading the water table heights when dark.

Groundwater table depth: Twelve piezometers were installed in the July 2018 rain phase based on topographic positions, two in the upslope (P1-P2), four in the midslope (P3-P6), and six in the downslope (P7-P12) portions of the watershed (Table 1). Piezometers were made of PVC pipes with a diameter of $5 \mathrm{~cm}$. Holes were drilled in the bottom $30 \mathrm{~cm}$ and wrapped with filter fabric to prevent soil entering. Water table depth was measured manually at 6:00 in the morning each day. Piezometers were located at $5 \mathrm{~m}$ distance upslope and downslope of the V-notch weirs from experimental fields. Measurements started in July 2018.

Infiltration: The infiltration rate was measured by a Guelph permeameter (Figure 3) that measures the rate of infiltrating water under a slightly negative pressure [32]. Measurements continued until three consecutive readings at 2-min intervals were the same, indicating that steady state was reached. These infiltration measurements included locations measured near the V-notch weirs. Measurements were done on 16 August 2018.

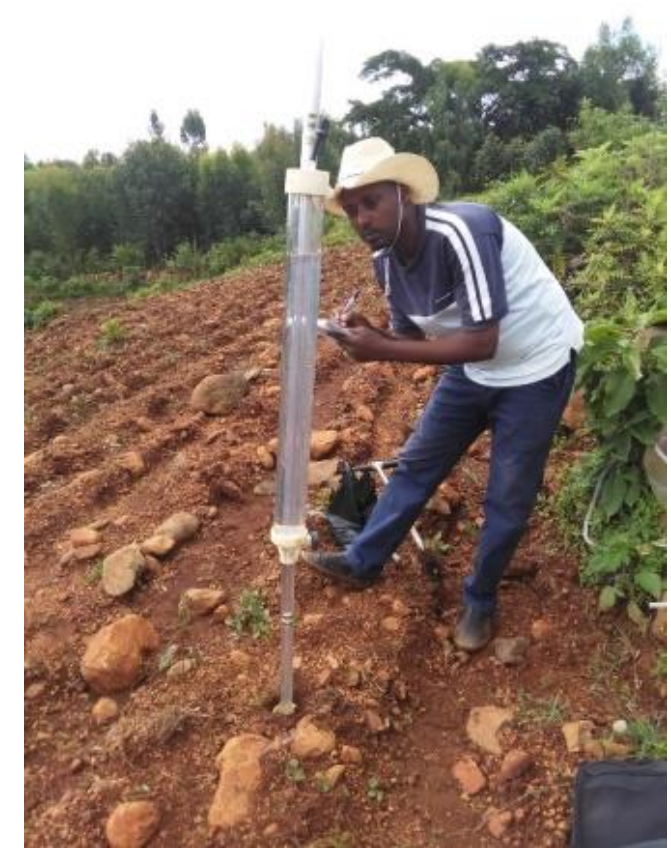

Figure 3. Field measurements of infiltration rate using a Guelph permeameter.

Data analysis: The Spearman rank correlation was used to quantify the relation between groundwater table and surface runoff, rainfall versus runoff, and rainfall intensity versus runoff. The correlation coefficient $(\mathrm{r})$ varies between 1 and -1 , with values close to zero indicating no correlation and values near 1 or -1 showing a strong correlation. Analysis of variance (ANOVA) was used to analyze the differences between the landscape 
positions in terms of hydrological response. Rainfall-runoff and water table depth versus surface runoff were plotted with time to explain the results graphically.

\section{Results}

\subsection{Precipitation}

Total precipitation for the 2017 rainy season was $1040 \mathrm{~mm}$, and in 2018, $980 \mathrm{~mm}$. The maximum daily rainfall was $65 \mathrm{~mm} \mathrm{~d}^{-1}$ on 08 August 2017. In 2018, the maximum was $60 \mathrm{~mm} \mathrm{~d}^{-1}$ on 16 August 2018 . The maximum hourly rainfall intensity was $38 \mathrm{~mm} \mathrm{~h}^{-1}$ in 2017 and $25 \mathrm{~mm} \mathrm{~h}^{-1}$ in 2018.

\subsection{Surface Runoff}

The cumulative rainfall and runoff coefficients for each daytime storm are shown in Figure 4 . The annually averaged runoff coefficients for the observed runoff events of the individual fields and averaged per slope position are shown in Table 2. The runoff per storm for the downslope fields was significantly greater than the upslope and midslope fields $(p<0.05)$. Although the runoff coefficients were not significantly different between up and midslope, the number of runoff events at the midslope in 2018 was approximately half of that in the upslope, indicating that the steeper midslope had less runoff than the flatter upper part (slopes of the land are given in Table 1). In the dryer 2018, the runoff coefficients were generally less than in 2017 in the upslope and downslope fields but not in the midslope (Figure 4). Runoff started earlier on more fields upslope than the downslope fields.

Table 2. Average annual runoff coefficients during the rain phase for the upslope, midslope, and downslope topographic positions in the Debre Mawi watershed in 2017 and 2018. The average runoff coefficient for each slope position was obtained by averaging all storms on the three fields for the slope position. Runoff started on 29 June 2017 and 8 July 2018.

\begin{tabular}{cccc}
\hline $\begin{array}{c}\text { Topographic } \\
\text { Position }\end{array}$ & $\mathbf{2 0 1 7}$ & $\begin{array}{c}\text { Runoff Coefficient } \\
\mathbf{2 0 1 8}\end{array}$ & Average \\
\hline upslope V1 & 0.39 & 0.14 & 0.28 \\
upslope V2 & 0.51 & 0.15 & 0.25 \\
upslope V3 & 0.43 & 0.31 & 0.34 \\
upslope average & $\mathbf{0 . 4 4}$ & $\mathbf{0 . 2 1}$ & $\mathbf{0 . 2 9}$ \\
midslope V5 & 0.35 & 0.42 & 0.39 \\
midslope V6 & 0.2 & 0.31 & 0.25 \\
midslope average & $\mathbf{0 . 2 7}$ & $\mathbf{0 . 3 1}$ & $\mathbf{0 . 2 9}$ \\
downslope V7 & 0.86 & 0.62 & 0.71 \\
downslope V8 & 0.89 & 0.59 & 0.69 \\
downslope V9 & 0.89 & 0.78 & 0.85 \\
downslope average & $\mathbf{0 . 8 8}$ & $\mathbf{0 . 6 3}$ & $\mathbf{0 . 7 3}$ \\
\hline
\end{tabular}



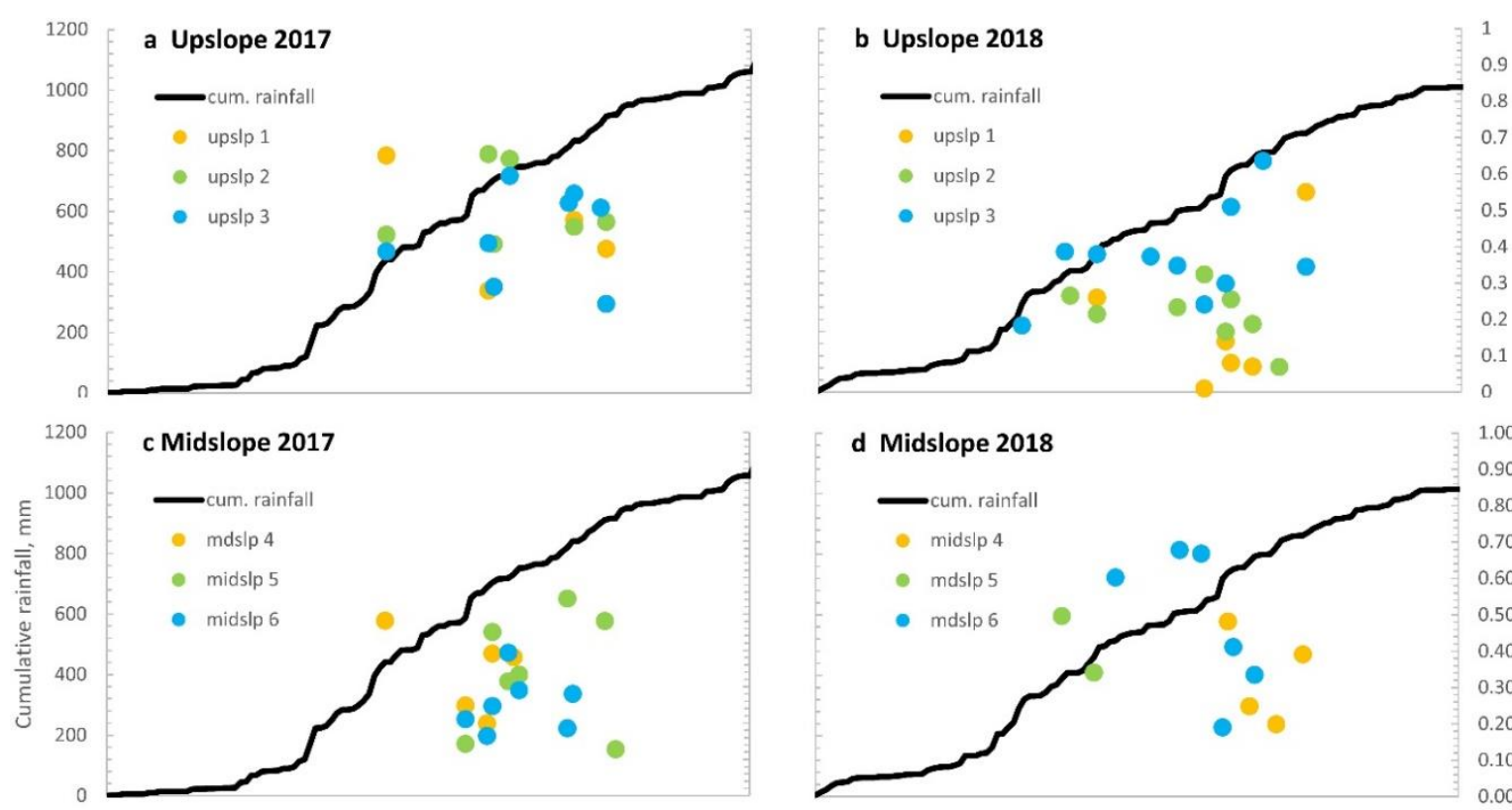

d Midslope 2018
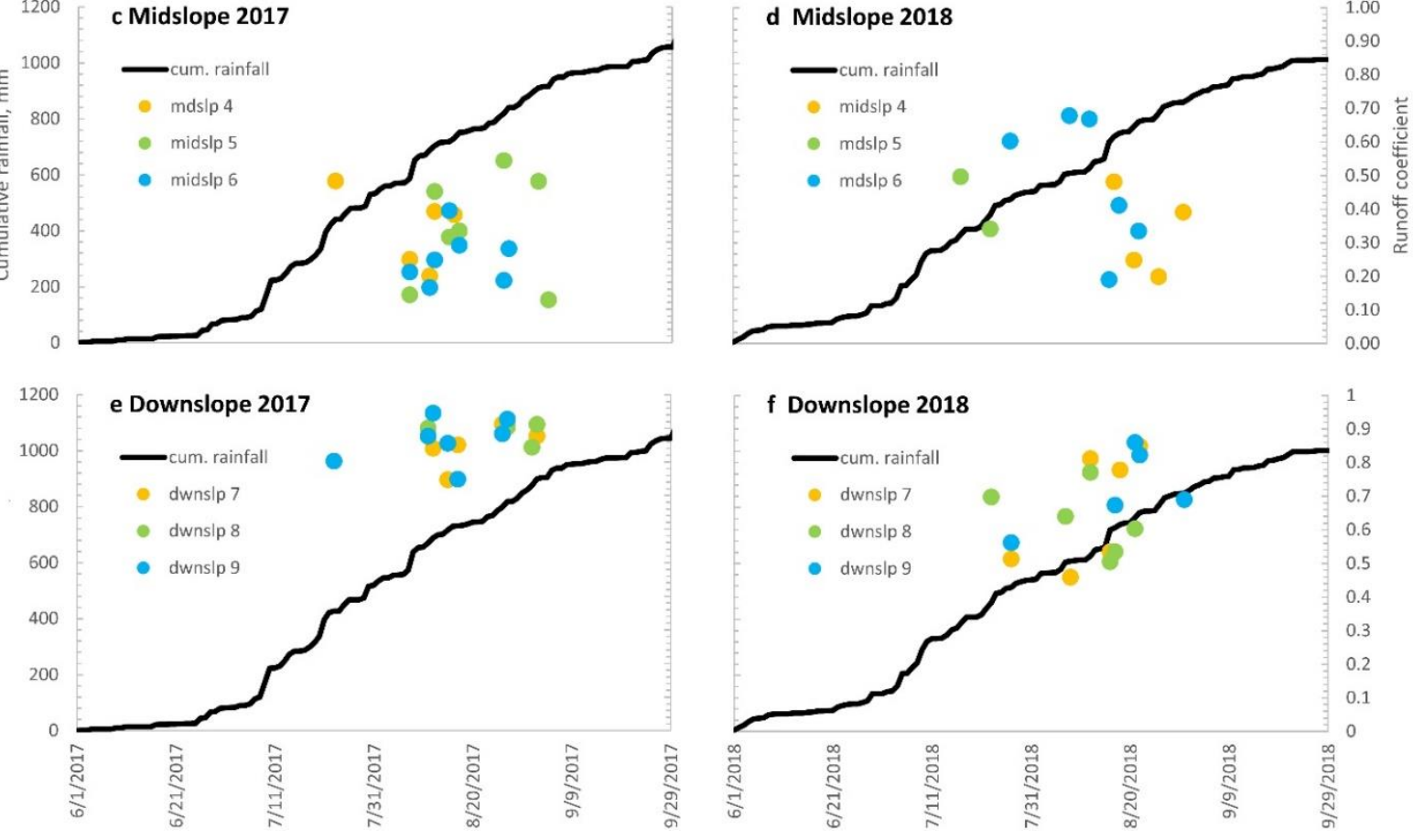

Figure 4. Cumulative precipitation and the runoff coefficients of the individual storms for the upslope, midslope, and downslope positions in the 2017 and 2018 rain phases. The symbols indicate the runoff coefficients for the upslope (a) in 2017 and (b) in 2018; the midslope (c) in 2017 and (d) in 2018 and downslope (e) in 2017 and (f) in 2018.

\subsection{Groundwater Table Depth}

Perched groundwater tables were monitored daily during the 2018 rain phase starting on 22 July. By that date, the groundwater downslope was less than $1 \mathrm{~m}$ from the surface; at midslope, it was 1 to $1.5 \mathrm{~m}$ below the surface, and upslope the groundwater was around 2 to $2.6 \mathrm{~m}$ deep. The water level in all downslope piezometers (P8-P12) had reached the soil surface on 26 July. P11 started to decrease on 15 August. Others at various times after that. P10 and P12 were the last ones to decline around 25 September. The water table in the midslope and upslope positions reached its maximum on 17 and 18 August 2018 (Figure 5). The variability in water table depths in the midslope region was the greatest. After a period without significant rainfall, the water table decreased. The variability in water table depths was the least in the downslope position since the soil surface limited it. Here, when the storage capacity of the profile was not sufficient, water flowed over the surface downhill. 


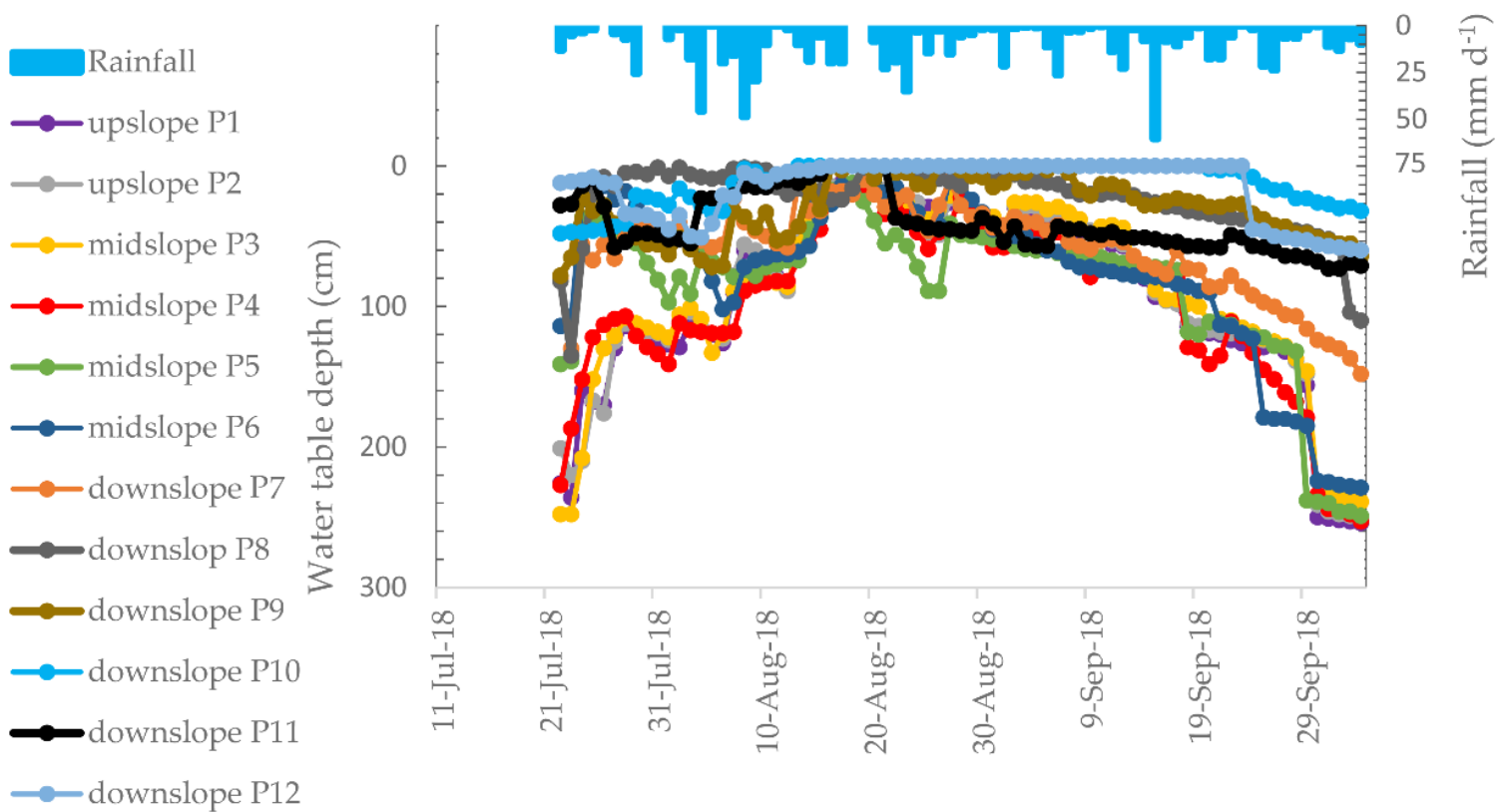

Figure 5. Water table depth for the slope positions in the Debre Mawi watershed.

\subsection{Infiltration}

Infiltration rates varied between $330 \mathrm{~mm} \mathrm{~h}^{-1}$ and $390 \mathrm{~mm} \mathrm{~h}^{-1}$ in the upslope and $27 \mathrm{~mm} \mathrm{~h}^{-1}$ to $90 \mathrm{~mm} \mathrm{~h}^{-1}$ in the midslope (Table 3). In the downslope positions, infiltration was zero (Table 3). The infiltration rates were affected by the water table height on the measurement date and would have been greater and only dependent on the soil texture when measured in the dry phase when the perched water table was absent.

Table 3. Infiltration rate and groundwater table depth measured on 16 August 2018 in the Debre Mawi watershed.

\begin{tabular}{ccc}
\hline Topographic Position & Infiltration Rate $\left(\mathbf{m m ~ h} \mathbf{h}^{-\mathbf{1}}\right)$ & $\begin{array}{c}\text { Water Table Depth from the } \\
\text { Surface } \mathbf{( c m})\end{array}$ \\
\hline upslope V1 & 330 & 31 \\
upslope V2 & 390 & 27 \\
upslope V3 & 330 & 21 \\
midslope V4 & 90 & 17 \\
midslope V5 & 30 & 13 \\
midslope V6 & 27 & 8 \\
downslope V7 & 0 & 0 \\
downslope V8 & 0 & 0 \\
downslope V9 & 0 & 0 \\
\hline
\end{tabular}

\section{Discussion}

Below we discuss the relationship between the runoff coefficients, infiltration rates, groundwater depth, and slope position.

\subsection{Relationship of Groundwater Table Depth, Slope Position and Distance from the Divide}

In Figure 6, the averaged groundwater table depth was plotted for each of the three slope positions. The ANOVA indicated that the difference in average water table depth among slope positions was statistically significant. The average water table depth in the upslope piezometers was $95 \mathrm{~cm}$; midslope piezometers had an average depth of $82 \mathrm{~cm}$. The water level downslope piezometers were on average $30 \mathrm{~cm}$ from the surface (Figure 6). Upslope piezometers were an average of $80 \mathrm{~m}$ from the watershed divide. The distance from the divide was $210 \mathrm{~m}$ midslope and $420 \mathrm{~m}$ downslope. 


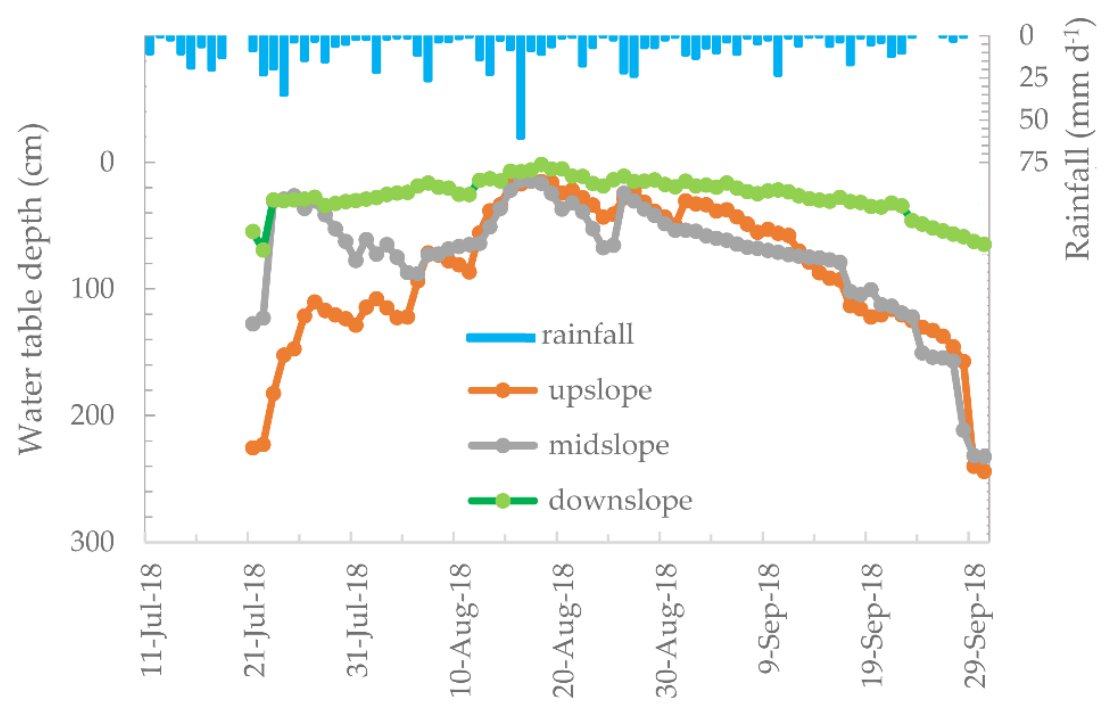

Figure 6. Average groundwater table depth for the upslope, midslope, and downslope positions of the Debre Mawi watershed in the 2018 rain phase. The water table measurements started on 22 July 2018 .

The depth and the patterns of the groundwater varied at the three slope positions. As shown in Figure 6, the general trend of the water table was that it rose in July, reached its peak in August, and decreased in September following the decrease in rainfall. The downslope positions have nearly constant water table depth during the rain phase compared to the mid slopes (Figure 6) since any incoming flow increases the overland flow [33]. Water table depth patterns are similar to those in the humid Ethiopian highlands $[6,23,33,34]$. Compared to the humid highlands, the water table comes for fewer locations in the semi-arid highlands and shorter times to the surface in the rain phase $[11,35]$.

It was previously shown that water table height is directly proportional to the recharge over the travel time from the watershed divide to the piezometer divided by the drainable porosity $[17,36]$. The studies confirm the importance of travel time on groundwater behavior [17]. The upslope piezometers had the shortest travel time, the water table exhibited short-term fluctuations and was farthest from the surface (Figure 5). The midslope piezometer had a longer travel time, damping short-term fluctuation in rainfall and a shallower groundwater table. Finally, the downslope piezometers have the longest travel time and are, therefore, most dampened. Moreover, the water table rise is limited by the land surface $[17,36,37]$.

\subsection{Hydrological Correlation Analysis on Seasonal Averaged Data}

\subsubsection{Infiltration Rate as a Function of Groundwater Table Depth}

We plotted both infiltration rates with the slope of the field and the water table depth. Both show a good correlation, but groundwater depth (Figure 7) was more relevant because groundwater depth plays an important role in soil saturation in the saturated excess runoff generating regions $[2,14,15,23,38]$. Interestingly, in other studies, the infiltration rate measurements in the Debre Mawi and other watersheds downslope are not zero but low. The difference is caused by how the infiltration rates were measured. This study uses the Guelph permeameter, where the water is applied under a small suction. For the ring infiltrometer, the applied water pressure is positive and equal to the height of the water level in the ring. Thus, for the ring infiltrometer, the water pressure is greater than the water in the soil, pushing the water in the soil and displacing water in the saturated soil. The displaced water will then flow downslope. 


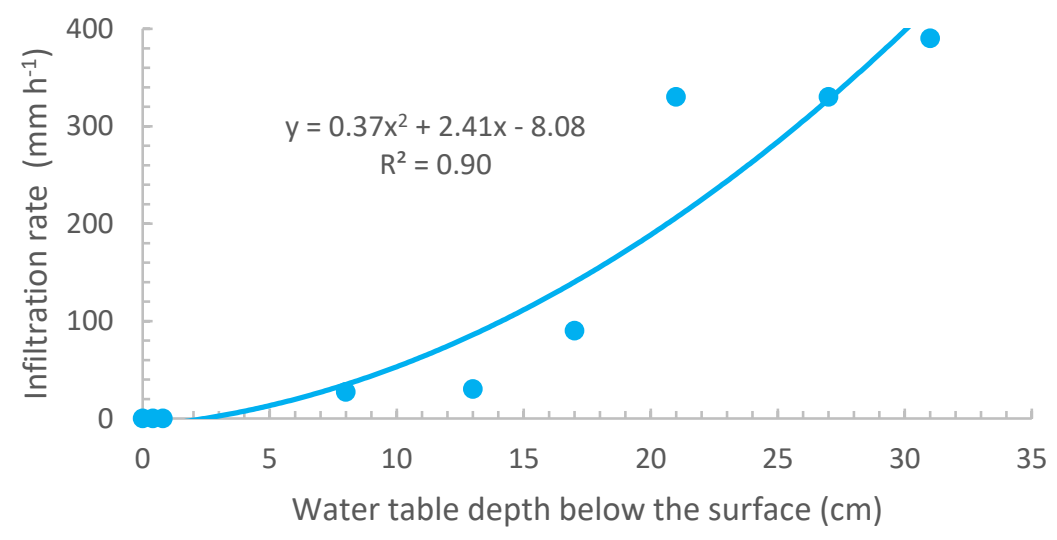

Figure 7. Infiltration rate vs. groundwater table depth in the Debre Mawi watershed. Groundwater table depth values taken on the same date with infiltration rate are plotted.

The positive relationship with groundwater depth can be explained by considering hydraulic gradient. The Guelph permeameter applies the water under suction. For an equilibrium soil profile (i.e., no water movement), the matric potential at the surface is equal to the groundwater depth. Assuming that the equilibrium soil profile is minimally disturbed by the infiltrating water, the suction at the wetting front of the water infiltrated from the infiltrometer is related to the depth of the groundwater minus the suction under which the water is applied. Hence, the flux is directly proportional to the distance to the water table for similar soils. Thus, as shown in Figure 7, for water tables at the surface, the infiltration is zero, and for the upslope fields, the infiltration rates were the greatest when the water tables were around $30 \mathrm{~cm}$ below the surface.

\subsubsection{Interaction of Runoff with Rainfall Amount}

The relationship between daily rainfall amount and daily surface runoff was weakly correlated with Spearman rank correlation (r) values of 0.26 downslope, 0.21 midslope, and 0.43 upslope. At first, the low correlations were unexpected because greater daily precipitation should result in more runoff. However, in the case of the Ethiopian highlands, where saturation excess runoff is common, the soil needs to become saturated before runoff occurs. After the ground becomes saturated, runoff is a function of the cumulative rainfall [1,2]. This phenomenon was well demonstrated at the downslope field (Figure 4). Once the runoff started, the runoff coefficients increased from zero to near one. Between storms, the uphill fields drain, keeping the downslope fields saturated with a smaller slope. This finding aligns with the report by [39], which identified that groundwater table depth is the major factor for the rainfall-runoff relationship. Groundwater table depth is directly related to landscape position.

In the second year, when the rainfall was less by $60 \mathrm{~mm}$, the runoff coefficients were smaller for the upslope and downslope position than the wetter first year, but not for the middle positions (Table 2). Earlier studies in the Debre Mawi watershed [22-24,33] have shown that the water balance did not close, and thus water left the watershed other than through the gauge. It was likely through fractures [40,41]. Assuming the subsurface flow was independent of the rainfall during the rain phase, this could explain the smaller runoff coefficients for the fractured downslope and upslope regions, but not for the midslope fields that were located in the region with the volcanic dikes, forcing the fractured flow to the surface [33].

\subsection{Effect of Slope Position and Soil Type on Runoff and Infiltration Capacity}

Nitisols (classified as clay loam) in the upslope position of the watershed is welldrained and permeable. The nitric-vertisols (classified as clay soil) dominant in the midslopes are shallower than the upslope and downslope soils. The downslope soils are vertisols (heavy clay), which, despite more than $91 \%$ clay, have a high infiltration rate when 
dry because they have a large crack network that allows water infiltration. Gerda [42] also noted that dry soils with cracks have a greater infiltration rate than wet soils. Early rainfalls, therefore, did not cause runoff from these vertisols. Only after they became wet and the water table was near the surface, infiltration rate was low, or zero, and nearly all rainfall ran off (Tables 2 and 3). Similarly, the runoff was negligible at the beginning of the rain phase in the upslope with nitisols and the midslope with nitric-vertisols. Runoff coefficients increased after the soils wetted up (Tables 1 and 2; Figure 4).

\subsection{Interaction of Land Use and Slope Position with Runoff}

An ANOVA was calculated to investigate the effect of crop type and slope position on runoff based on the storm runoff values. Upslope, the runoff coefficients of finger millet and teff (Tables 1 and 2) were not significantly different $(p=0.21)$. Similarly, midslope runoff coefficients for teff (V4 and V6, Tables 1 and 2) and wheat (V5, Tables 1 and 2) did not differ significantly. In contrast, the runoff coefficients of teff upslope (V1 and V2, Table 2) were significantly less than downslope (V7-V9, Table $2(p=0.02$.)). Commonly it is assumed that infiltration excess depends on land use and not on slope position.

Consequently, our results were opposite infiltration excess behavior. Another study in the Ethiopian highlands $500 \mathrm{~km}$ east from the current site also concluded that topography controlled the amount of discharge compared to ecological factors [6]. Savenije [10] opinionated that runoff was topographically driven. These findings are especially important for modeling studies that base their runoff prediction on the SCS curve number approach, where the curve number is a function of the crop grown [14].

\section{Conclusions}

Topographic positions control the hydrological processes and hence the sources of hydrologic variability in agricultural watersheds in the Ethiopian (sub) humid highlands. The surface runoff, groundwater table depth, and soil type are highly linked with the topographic position of a landscape unit. During the rain phase, the groundwater table was deeper in the upslope, shallower in the midslope, and at the surface in the downslope positions in the humid Debre Mawi watershed. The infiltration rate was high upslope, low in the midslope, and zero in the downslope. Runoff coefficients were greater downslope than midslope and upslope. This study suggests that the implementation of landscapespecific soil and water conservation practices in the sub-humid and humid Ethiopian highlands should be based on slope position. In addition, parameterization of models should take into account that downslope fields produce greater amounts of runoff after the soils become saturated.

Author Contributions: D.A.M. and M.G.D. collected the data, and D.A.M. wrote the initial draft of the manuscript. M.G.D., D.C.D., F.A.Z., S.A.T., B.F.Z. and T.S.S. analyzed and advised in the research that led to this paper. K.W. and W.B.A. aided in the analysis of the results. C.D.G., T.S.S., F.A.Z., S.A.T. and B.F.Z. supervised the research and revised and edited the manuscript. All authors have read and agreed to the published version of the manuscript.

Funding: Funding for this research was provided in part by the Belmont Forum NILE-NEXUS project through the United States NSF award ICER-1624335. Additional funding was also obtained from the Blue Nile Water Institute, Bahir Dar University.

Data Availability Statement: The data presented in this study are openly available in https:/ /hdl. handle.net/1813/110709, accessed on 28 October 2021.

Acknowledgments: The data collectors were instrumental in collecting the runoff amounts at a moment's notice when the rain started. We thank the farmers and their families in the Debre Mawi watershed for their hospitality and cooperation. Without them, the research could not have been carried out.

Conflicts of Interest: The authors declare that they do not have conflicting interest. 


\section{References}

1. Liu, B.M.; Collick, A.S.; Zeleke, G.; Adgo, E.; Easton, Z.M.; Steenhuis, T.S. Rainfall-discharge relationships for a monsoonal climate in the Ethiopian highlands. Hydrol. Process. 2008, 22, 1059-1067. [CrossRef]

2. Tilahun, S.A.; Guzman, C.D.; Zegeye, A.D.; Ayana, E.K.; Collick, A.S.; Yitaferu, B.; Steenhuis, T.S. Spatial and Temporal Patterns of Soil Erosion in the Semi-humid Ethiopian Highlands: A Case Study of Debre Mawi Watershed. In Nile River Basin; Springer: Berlin/Heidelberg, Germany, 2014; pp. 149-163. [CrossRef]

3. McDonnell, J.J. Hewlett, J.D.; Hibbert, A.R. Factors affecting the response of small watersheds to precipitation in humid areas. In Forest Hydrology; Sopper, W.E., Lull, H.W., Eds.; Pergamon Press: New York, NY, USA, 1967; pp. 275-290. Phys. Geogr. Earth Environ. 2009, 33, 288-293. [CrossRef]

4. McMillan, H. Linking hydrologic signatures to hydrologic processes: A review. Hydrol. Process. 2019, 34, 1393-1409. [CrossRef]

5. Bayabil, H.K.; Tebebu, T.Y.; Stoof, C.R.; Steenhuis, T.S. Spatial and temporal runoff processes in the degraded Ethiopian Highlands: The Anjeni Watershed. Hydrol. Earth Syst. Sci. Discuss. 2015, 12, 4387-4411. [CrossRef]

6. Bayabil, H.K.; Tilahun, S.A.; Collick, A.S.; Yitaferu, B.; Steenhuis, T.S. Are runoff processes ecologically or topographically driven in the (sub) humid Ethiopian highlands? The case of the Maybar watershed. Ecohydrology 2010, 3, 457-466. [CrossRef]

7. Akale, A.T.; Dagnew, D.C.; Belete, M.A.; Tilahun, S.A.; Mekuria, W.; Steenhuis, T.S. Impact of Soil Depth and Topography on the Effectiveness of Conservation Practices on Discharge and Soil Loss in the Ethiopian Highlands. Land 2017, 6, 78. [CrossRef]

8. Guillén, L.A.; Fernández, R.; Gaertner, B.; Zégre, N.P. Climate and Landscape Controls on the Water Balance in Temperate Forest Ecosystems: Testing Large Scale Controls on Undisturbed Catchments in the Central Appalachian Mountains of the US. Water Resour. Res. 2021, 57, 2411-2502. [CrossRef]

9. Camporese, M.; Paniconi, C.; Putti, M.; McDonnell, J.J. Fill and Spill Hillslope Runoff Representation with a Richards EquationBased Model. Water Resour. Res. 2019, 55, 8445-8462. [CrossRef]

10. Savenije, H.H.G. HESS Opinions Topography driven conceptual modelling (FLEX-Topo). Hydrol. Earth Syst. Sci. 2010, 14, 2681-2692. [CrossRef]

11. Nyssen, J.; Clymans, W.; Descheemaeker, K.; Poesen, J.; Vandecasteele, I.; Vanmaercke, M.; Zenebe, A.; Van Camp, M.; Haile, M.; Haregeweyn, N.; et al. Impact of soil and water conservation measures on catchment hydrological response-a case in north Ethiopia. Hydrol. Process. 2010, 24, 1880-1895. [CrossRef]

12. Assefa, T.T.; Jha, M.K.; Tilahun, S.A.; Yetbarek, E.; Adem, A.A.; Wale, A. Identification of Erosion Hotspot Area using GIS and MCE Technique for Koga Watershed in the Upper Blue Nile Basin, Ethiopia. Am. J. Environ. Sci. 2015, 11, 245-255. [CrossRef]

13. Mhiret, D.A.; Dagnew, D.C.; Assefa, T.T.; Tilahun, S.A.; Zaitchik, B.F.; Steenhuis, T.S. Erosion hotspot identification in the sub-humid Ethiopian highlands. Ecohydrol. Hydrobiol. 2019, 19, 146-154. [CrossRef]

14. Moges, M.A.; Schmitter, P.; Tilahun, S.A.; Langan, S.; Dagnew, D.C.; Akale, A.T.; Steenhuis, T.S. Suitability of Watershed Models to Predict Distributed Hydrologic Response in the Awramba Watershed in Lake Tana Basin. Land Degrad. Dev. 2017, 28, $1386-1397$. [CrossRef]

15. Akale, A.T.; Dagnew, D.C.; Moges, M.A.; Tilahun, S.A.; Steenhuis, T.S. The Effect of Landscape Interventions on Groundwater Flow and Surface Runoff in a Watershed in the Upper Reaches of the Blue Nile. Water 2019, 11, 2188. [CrossRef]

16. Tilahun, S.A.; Guzman, C.D.; Zegeye, A.D.; Engda, T.A.; Collick, A.S.; Rimmer, A.; Steenhuis, T.S. An efficient semi-distributed hillslope erosion model for the subhumid Ethiopian Highlands. Hydrol. Earth Syst. Sci. 2013, 17, 1051-1063. [CrossRef]

17. Alemie, T.C.; Tilahun, S.A.; Ochoa-Tocachi, B.F.; Schmitter, P.; Buytaert, W.; Parlange, J.; Steenhuis, T.S. Predicting Shallow Groundwater Tables for Sloping Highland Aquifers. Water Resour. Res. 2019, 55, 11088-11100. [CrossRef]

18. Sultan, D.; Tsunekawa, A.; Haregeweyn, N.; Adgo, E.; Tsubo, M.; Meshesha, D.T.; Masunaga, T.; Aklog, D.; Fenta, A.A.; Ebabu, K. Efficiency of soil and water conservation practices in different agro-ecological environments in the Upper Blue Nile Basin of Ethiopia. J. Arid Land 2018, 10, 249-263. [CrossRef]

19. Huang, C.; Gascuel-Odoux, C.; Cros-Cayot, S. Hillslope topographic and hydrologic effects on overland flow and erosion. Catena 2002, 46, 177-188. [CrossRef]

20. Cerdà, A.; Rodrigo-Comino, J. Is the hillslope position relevant for runoff and soil loss activation under high rainfall conditions in vineyards? Ecohydrol. Hydrobiol. 2020, 20, 59-72. [CrossRef]

21. Tebebu, T.Y.; Abiy, A.Z.; Zegeye, A.D.; Dahlke, H.E.; Easton, Z.M.; Tilahun, S.A.; Collick, A.S.; Kidnau, S.; Moges, S.; Dadgari, F.; et al. Surface and subsurface flow effect on permanent gully formation and upland erosion near Lake Tana in the northern highlands of Ethiopia. Hydrol. Earth Syst. Sci. 2010, 14, 2207-2217. [CrossRef]

22. Tilahun, S.A.; Guzman, C.D.; Zegeye, A.D.; Dagnew, D.C.; Collick, A.S.; Yitaferu, B.; Steenhuis, T.S. Distributed discharge and sediment concentration predictions in the sub-humid Ethiopian highlands: The Debre Mawi watershed. Hydrol. Process. 2015, 29, 1817-1828. [CrossRef]

23. Dagnew, D.C.; Guzman, C.D.; Zegeye, A.D.; Tebebu, T.Y.; Getaneh, M.; Abate, S.; Zemale, F.A.; Ayana, E.K.; Tilahun, S.A.; Steenhuis, T.S. Impact of conservation practices on runoff and soil loss in the sub-humid Ethiopian Highlands: The Debre Mawi watershed. J. Hydrol. Hydromech. 2015, 63, 210-219. [CrossRef]

24. Mhiret, D.A.; Dagnew, D.C.; Alemie, T.C.; Guzman, C.D.; Tilahun, S.A.; Zaitchik, B.F.; Steenhuis, T.S. Impact of Soil Conservation and Eucalyptus on Hydrology and Soil Loss in the Ethiopian Highlands. Water 2019, 11, 2299. [CrossRef] 
25. Mhiret, D.A.; Dagnew, D.C.; Guzman, C.D.; Alemie, T.C.; Zegeye, A.D.; Tebebu, T.Y.; Langendoen, E.J.; Zaitchik, B.F.; Tilahun, S.A.; Steenhuis, T.S. A nine-year study on the benefits and risks of soil and water conservation practices in the humid highlands of Ethiopia: The Debre Mawi watershed. J. Environ. Manag. 2020, 270, 110885. [CrossRef] [PubMed]

26. Abiy, A.Z. Geological Controls in the Formations and Expansions of Gullies Over Hillslope Hydrological Processes in the Highlands of Ethiopia, Northern Blue Nile Region. Master's Thesis, Graduate School of Cornell University, Ithaca, NY, USA, August 2009.

27. Zegeye, A.D.; Steenhuis, T.S.; Blake, R.W.; Kidnau, S.; Collick, A.S.; Dadgari, F. Assessment of Upland Erosion Processes and Farmer Perception of Land Conservation in Debre Mewi Watershed, near Lake Tana, Ethiopia. Ecohydrol. Hydrobiol. 2011, 10, 297-306. [CrossRef]

28. Zegeye, A.D.; Langendoen, E.J.; Guzman, C.D.; Dagnew, D.C.; Amare, S.D.; Tilahun, S.A.; Steenhuis, T.S. Gullies, a critical link in landscape soil loss: A case study in the subhumid highlands of Ethiopia. Land Degrad. Dev. 2018, 29, 1222-1232. [CrossRef]

29. Tilahun, S.A.; Yilak, D.L.; Schmitter, P.; Langan, S.; Barron, J.; Parlange, J.Y.; Steenhuis, T.S. Establishing irrigation potential of a hillside aquifer in the African highlands. Hydrol. Process 2020, 34, 1741-1753. [CrossRef]

30. Shen, J. Discharge Characteristics of Triangular-Notch Thin-Plate Weirs: Studies of Flow to Water Over Weirs and Dams; USGPO: Washington, DC, USA, 1981. [CrossRef]

31. Greve, F.W. Flow of Water Through Circular, Parabolic, and Triangular Vertical Notch-Ueirs; Purdue University: West Lafayette, IN, USA, 1932.

32. Lee, D.M.; Elrick, D.E.; Reynolds, W.D.; Clothier, B.E. A Comparison of three field methods for measuring saturated hydraulic conductivity. Can. J. Soil Sci. 1985, 65, 563-573. [CrossRef]

33. Guzman, C.D.; Tilahun, S.A.; Dagnew, D.C.; Zimale, F.A.; Zegeye, A.D.; Boll, J.; Parlange, J.-Y.; Steenhuis, T.S. Spatio-temporal patterns of groundwater depths and soil nutrients in a small watershed in the Ethiopian highlands: Topographic and land-use controls. J. Hydrol. 2017, 555, 420-434. [CrossRef]

34. Engda, T.A.; Bayabil, H.K.; Legesse, E.S.; Ayana, E.K.; Tilahun, S.A.; Collick, A.S.; Easton, Z.M.; Rimmer, A.; Awulachew, S.B.; Steenhuis, T.S. Watershed Hydrology of the (Semi) Humid Ethiopian Highlands. In Nile River Basin; Springer: Dordrecht, The Netherlands, 2011; pp. 145-162. [CrossRef]

35. Walraevens, K.K.; Vandecasteele, I.; Martens, K.K.; Nyssen, J.; Moeyersons, J.J.; Gebreyohannes, T.T.; De Smedt, F.; Poesen, J.J.; Deckers, J.J.; Van Camp, M.M. Groundwater recharge and flow in a small mountain catchment in northern Ethiopia. Hydrol. Sci. J. 2009, 54, 739-753. [CrossRef]

36. McGlynn, B.L.; McDonnell, J.J. Quantifying the relative contributions of riparian and hillslope zones to catchment runoff. Water Resour. Res. 2003, 39. [CrossRef]

37. McGlynn, B.L.; McDonnell, J.J.; Seibert, J.; Kendall, C. Scale effects on headwater catchment runoff timing, flow sources, and groundwater-streamflow relations. Water Resour. Res. 2004, 40. [CrossRef]

38. Jencso, K.G.; McGlynn, B.L.; Gooseff, M.; Wondzell, S.M.; Bencala, K.E.; Marshall, L. Hydrologic connectivity between landscapes and streams: Transferring reach- and plot-scale understanding to the catchment scale. Water Resour. Res. 2009, 45. [CrossRef]

39. Han, S.; Xu, D.; Wang, S. Runoff formation from experimental plot, field, to small catchment scales in agricultural North Huaihe River Plain, China. Hydrol. Earth Syst. Sci. 2012, 16, 3115-3125. [CrossRef]

40. Yenehun, A.; Nigate, F.; Belay, A.S.; Desta, M.T.; Van Camp, M.; Walraevens, K. Groundwater recharge and water table response to changing conditions for aquifers at different physiography: The case of a semi-humid river catchment, northwestern highlands of Ethiopia. Sci. Total Environ. 2020, 748, 142243. [CrossRef] [PubMed]

41. Adem, A.A.; Addis, G.G.; Aynalem, D.W.; Tilahun, S.A.; Mekuria, W.; Azeze, M.; Steenhuis, T.S. Hydrogeology of Volcanic Highlands Affects Prioritization of Land Management Practices. Water 2020, 12, 2702. [CrossRef]

42. Cerdà, A. Seasonal variability of infiltration rates under contrasting slope conditions in southeast Spain. Geoderma 1996, 69, 217-232. [CrossRef] 